\title{
TEORI GANTI RUGI (DHAMAN) PERSPEKTIF HUKUM ISLAM
}

Oleb: Asmuni Mth*

\section{Abstract}

The idea of dhaman towards both criminal and justice victims, from early time, has been mentioned in the nash of both Al-Quran and Al-Hadith. From the nash, Ulemas bave formulated various figh forms concerning dhaman (compensation). In fact, from early time the Islamic Jurists bave not applied the terms mas'uliyah madaniyah for justice responsibility, and mas'uliyah al-jina'iyah for criminal one. Although in its development, up to recent time, Islamic Jurists often use the term mas'uliyah that is because of the. Western work influences. Dhaman could occur because of deviation on akad (agreement) namely dhaman al-aqdi, and could bappen because of violation namely dhaman 'udwan. Dharar could occur on physical, material or things and service aspects; and it could also be on moral and emotional destruction or called darar adabi including name-reputation damage. The standard for the compensation either on quality or quantity must be similar to dharar suffered by the victims. Although in certain cases, the multiplying compensation may bappen based on the victims' condition.

a) $(4)$

استحرذت فكرة ضمان العلوان، زمعتراها الرتيس منح التعويض للمتضرر بسبب جناتي أو بسبب

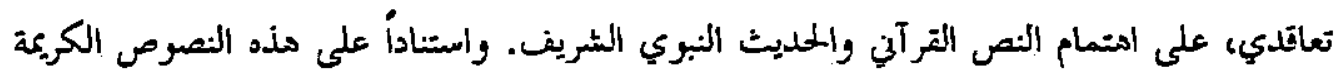
نجه العلماء والفقهاء المملمرذ في صرغ قواعد فقهية فيما يتعلت بالضمان أز التعويضات. وعلى

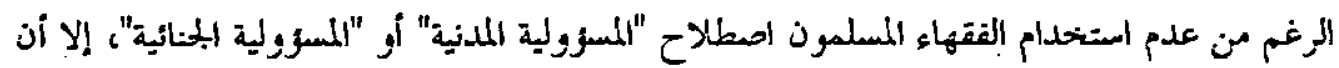
بعضاً من مفكري القانون الإسلامي التقليدي. أنما في المرحلة المحالية من تطور الفقه الإسلامي، فيغلب

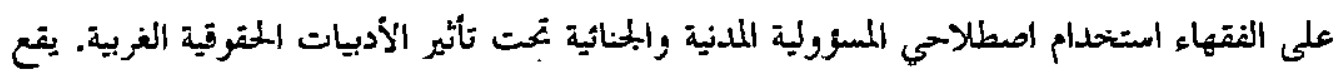

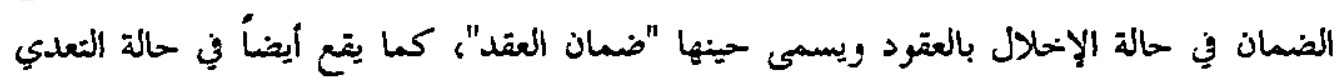
ويدعى حينها "ضمان العدوان". قد يحدث الضرر في البحانب المادي، المالي، السلعي، الملدمي، أو

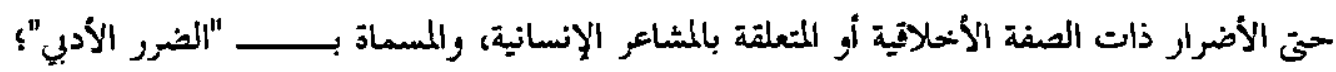

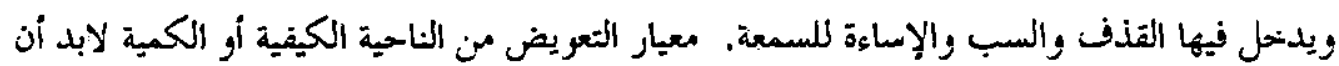
يترافق مع حجم الضرر الواقع على المتضرر، إلا أنه في بعض الحالات قد يضاعف التعريض أو الضمان في مساوقة مع موقف المتعدي أو الملاني.

Key words: Dhaman, Mas'uliyab Jina'iyah, Mas'uliyah Madaniyah, Dharar

Penulis adalah Dosen Fakultas Ilmu Agama Islam Universitas Islam Indonesia Yogyakarta. 


\section{A. Pendabuluan}

Secara kualitatif maupun kuantitatif, pada dasanya hukum Islam melindungi kemaslahatan setiap individu di tengah masyarakat. Perlindungan tersebut meliputi aspek agama, jiwa, keturunan, akal, dan harta. Semua orang diwajibkan untuk menghormati kelima hak tersebut dan bekerja secara sungguh-sungguh untuk memeliharanya. Dalam konteks ini Al-Qur'an menjelaskan bahwa man qotala nafsan bigairi nafsin awu fasâdin fi al-ardh fakaannamâ qotala al-nâsa jamî'a, juga man qotala mu'minan khotho'an fatabrîru roqobatin mu'minatin wa diyyatun musallamab ilâ ablihi.

Al-Qur'an juga mewajibkan berlaku adil dalam bermuamalah dan betlaku ihsân kepada kerabat, tetangga, dan umat Islam secara keseluruhan. Al-Qur'an melarang makan harta orang lain dengan cara batil, mewajibkan gisas terhadap pelaku pembunuhan yang zalim untuk menghilangkan darar pada korban: wa jaz al-'u sayjiatin sayyiatun mislubâ, juga famani' tadâ 'alaikum fa'tadu 'alaibi bi misli mani'tada 'alaikum. Islam juga meletakkan prinsip-prinsip tanggung jawab seseorang terhadap perbuatannya, bukan atas perbuatan orang lain: fakullu nafsin bimâ kasabat rabinah, juga wa likulli insânin ma kasaba wa 'alaibi ma iktasaba, serta walâ tąiru wấiratun wizra ukhrâ dan prinsip-prinsip lainnya yang belum dikenal oleh sistem hukum Barat kecuali di zaman modern ini.

Sunnah Nabi pun muncul untuk memperkuat :makna prinsip pertanggungjawaban tersebut. Ditegaskan oleh Nabi Muhammad bahwa al-muslim akbu al-muslim la yazlimubu wala yakhzulubu. Sunah Nabi juga meletakkan pondasi kaidah-kaidah umum yang bertujuan untuk menghilangkan darar secara mutlak seperti disebutkan oleh hadis Nabi Lâ darara walâ diroro. Pada saat haji wada' (haji perpisahan) Nabi juga menegaskan dasar-dasar umum untuk kehidupan sosial yang anggun dan bermartabat. Pada saat-saat terakhir kehidupan Muhammad,--beliau mewajibkan dhaman (ganti rugi) pada perbuatan yang berlatar belakang ta'addi (pelanggaran terhadap hukum) pada amwal (harta), al-mumtalikat (hak milik), $\cdot \mathrm{Nabi}$ menegaskan "ala al-yadi ma akbaqat-batta taruddubu".

Bertitik tolak dari prinsip-prinsip umum tersebut di atas, para fuqaha' memformulasikan kaidah-kaidah pertanggungjawaban (gawa'id al-masûliyab). Mereka melakukan identifikasi mana yang masuk dalam kategori kbitab al-taklif al-jinäi (pidana) yang berimplikasi pada al'uqubab (hukuman) terhadap pelaku (mukbolafatu awâmir al-syari' wa abk̆âmihi), dengan al-taklif bi dhaman (beban ganti rugi). Dalam hubungan inilah al-Qurafi dan 'Izzuddin Ibn Abdi al-Salam masing-masing dalam karya mereka al-Furuq dan al-Qawa'id al-Abkam menegaskan dan menjelaskan secara konkret perbedaan antara al-zawajir atau al-'uqubat dengan al-jawabir atau dhamanat. ${ }^{1}$

\footnotetext{
$\therefore$ Kenyataan ini kemudian menyimpan pertanyaan akan sumber perundang-undangan Barat yang sesungguhnya ketika membedakan antara al-masulizah al-jinaiyah (tanggung jawab pidana) dan al-masuliyab al-madanijah (tanggung jawab perdata), dan antara al-masuliyah al-tagshinjiah (tanggung jawab akibat
} 
Kaidah-kaidah universal yang menjadi teori umum dhaman antara lain adalah":

$$
\begin{aligned}
& \text { لاضرر ولا ضرار; والضرر يزال؛ والضضرورات تبيح المحظورات; والضرورات تقدر بقدرها; والضرر } \\
& \text { لا يزال .عثله; ويتحمل الضرر الماص للفع الضرر العانز والضرر الأشد يزال بالضرر الأخف; والضرر. }
\end{aligned}
$$

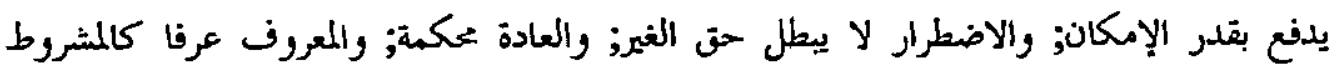

$$
\begin{aligned}
& \text { شرطاز والمعروف بين التجار كالمشروط بينهمز وإذا بطل الأصل يصار إلى البدل; ويلزم مراعاة }
\end{aligned}
$$

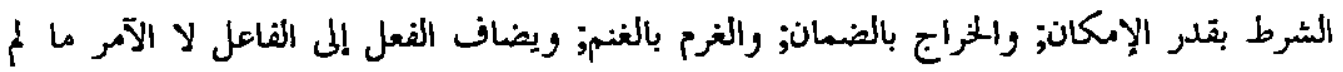

$$
\begin{aligned}
& \text { يكن بحمراز والمواز الترعي ينائ الضمان. }
\end{aligned}
$$

Demikian pula pada pasal-pasal lain dalam al-Majallab. Hukum-hukum·yang berkaitan dengan perampasan (al-gasb), misalnya, dimuat dalam pasal 890-912. hukum-hukum yang berkaitan dengan perusakan barang (itlâj) dimuat dalam pasal 912-942.

Tulisan ini tidak bermaksud melakukan perbandingan antara teori dhaman menurut figh dan hukum, apalagi melakukan kajian terhadap pengatuh hukum fiqh terhadap sistem hukum Barat terutama hukum Perancis. Tulisan ini hendak mengemukakan teori dbaman secara umum dan sebagian aplikasinya terhadap tanggung jawab seseorang atas perbuatannya.

\section{B. Pengertian Dbaman}

Secara etimologis, dbaman ${ }^{3}$ memiliki makna yang cukup beragam. Misalnya,

kecerobohan dan kelalaian) dan al-masuliyab al-agdiyab (tanggung jawab akibat pelanggaran perjanjian kontrak). Adalah sangat tidak mungkin model pembagian ini tanpa dipengaruhi oleh sistem hukum Islam.

Meski demikian al-Sanhur berkeyakinan bahwa sistem hukum Perancis adalah paling awal dalam menjelaskan masulyyah dan macam-macamnya dengan melakukan interpretasi terhadap hukum Romawi. Padahal hukum Romawi tidak melakukan pembagian al-masuliyah secara rinci seperti itu. Inilah yang ditegaskan oleh Sayyid Abdullah Husain ketika menolak pendapat Sanhuri dengan menyatakan: "Pengambilan' atau penyaduran dari mazhab Malik bukan dimulai pada tahun 1805, melainkan sejak tahun $200 \mathrm{H}$. Ketika Islam menguasai Eropa, Andalusia menjadi pusat ilmu pengetahuan, pada saat Eropa secara umum berada dalam kegelapan intelektual." Pada saat itu Islam masuk daratan Eropa dan . memerintah penduduknya serta membangun kaidah-kaidah hukum yang adil. Penduduk Eropa berdatangan ke Andalusia semata-mata untuk menimba ilmu pengetahuan. Abdullah Husain juga berpendapat bahwa hukum perdata Perancis yang menjadi sumber berbagai hukum saat ini adalah terambil dari mazhab Malik ibn Anas. Lihat Sayyid Abdullah Husain, "al-Mugaranât al-Tasyn' 'ýab", dalam Muhammad Ahmad Siraj (tt), Dhaman al-Udwan fi al-Figh al-Islami (Dirâsab Fighbjyah Mugẩanab bi ablấm almasulyyah al-Taqshinjyab fi al-qanun), al-Muassasah al-Jami'iyyah li al-Dirâsat wa al-Nasyr wa al-Tauzi', p. 15.

2 Mustofa Ahmad al-Zarqa' (tt), al-Madkhal al-Fiqhi al-Am (al-Fiqh al-Islami fi Saubihi al-Jadid), Beirut: Dar al-Fikr. pp. 19-91.

${ }^{3}$ Dalam karya-katya fiq̣h kontemporer istilah dhaman sering digandengkan dengan istilah al-masûtyah. 
menanggung, tanggung jawab, dan kewajiban. Dalam kamus Lisan al-'Arab, Ibnu Manzur menandaskan bahwa semua makna dhaman terkonsentrasi pada jaminan, penanggungan atau garansi. Makna yang tak jauh berbeda juga ditemukan dalam kamus al-Mubitht yang mengartikan dhaman dengan ganti rugi.

Dalam term figh, dhaman juga dimaknai beragam. ${ }^{5}$ Imam Ghazali, ${ }^{6}$ misalnya memaknai dhaman dengan "luqumu rad al-syayy' avu badalubu bil mitsli awu bil qimati (keharusan mengganti suatu barang dengan barang yang sama atau sepadan dengan nilai jualnya). Al-Hamawy ${ }^{7}$ pensyarah kitab al-Asybah wa al-Naza'ir karya Ibn Nujaim mengatakan bahwa dhaman adalah 'ibâratun 'an raddi misli al-bâlik awu qimatubu (mengganti barang yang rusak dengan barang yang sama atau yang sepadan dengan nilai jualnya). Sedangkan as-Syaukani ${ }^{8}$ mengatakan bahwa dhaman adalah. 'ibaratun 'an garamati al-tâlif (mengganti barang yang rusak).

Majallab al-Abkam al-Adliyab $b^{9}$ menyebutkan bahwa ganti rugi disesuiakan dengan jenis barang yang rusak (dbaman buwa itha'u misli al-syai' inkâna minal misliyât, waqimatubu inkâna minal qimiyât). Apabila jenisnya tergolong al-misliyât, maka ganti ruginya dengan barang yang sama (al-mish). Jika barang yang rusak tergolong alqimiyât, maka nilai ganti rugi disesuaikan dengan nilai jualnya di pasar (qimab). ${ }^{10}$ Menurut al-Zarqa'11 dhaman adalah iltizâm bi ta'widhin maliyin 'an darari al-gair. Sedangkan menurut al-Zuhaili dhaman adalah bua al-iltizâm bita'widhi al-gair 'amma labiqabu min talafi al-mal awn dhiyâ' al-manâfí, awu ishabatin min dhararin juz'i awu kulli bâdisun bi al-nafsi al-insâniyah awu bi'udhwin minbâ. ${ }^{12}$

Baik definisi al-Gazali maupun al-Majallab sama-sama membatasi dhaman pada

Dhaman sendiri mengandung makna ganti rugi, sedangkan al-masuliyah mengandung makna tanggung jawab. Dasar hukum syar'i tentang dhaman maupun al-masûliyah, antara lain yâ aijuhallazina âmanî la tasalût 'an asy-yâ in tubda lakum tasu'kum (al-Maidah: 101); fas'al bihi khabira (al-Furqon: 59); inna as-sam'a wa albashara wa al-fuâda kullu ulâika kâna 'anbu masûla (al-Isra': 36).

${ }^{4}$ Majduddin al-Fairuzabadi (tt), al-Qamus al-Muhit, Kairo: Dar al-Hadis, bagian dhaman.

${ }^{5}$ Definisi dbaman yang beragam mengarah pada makna menjamin (menanggung) untuk membayat utang, mengadakan barang, atau menghadirkan orang pada tempat yang telah ditentukan. Karena itu, biasanya dhaman mengandung tiga masalah pokok, yaitu (1) jaminan atas utang seseorang; (2) jaminan dalam pengadaan barang; dan (3) jaminan dalam menghadirkan seseorang di tempat tertentu, seperti pengadilan.

${ }^{6}$ al-Gazali, al-IVajiz, hal. I/208.

${ }^{7}$ Ahmad Ibn Muhammad al-Hamawy (1405 H/1985), Gamzu Uyini al-Basha'ir wa Syarah alAsybâh wa al-Nâza'ir, Bairut: Dar al-Kutub al-ilmiah, Jilid. II. p. 211.

${ }^{8}$ As-Syaukani $(1380 \mathrm{H})$, Nail al-Authar Syarh Muntaqa al-Akbbar, Mesir. Mustafa al-Babi al-Halabi, Jilid. V. p. 299.

\footnotetext{
${ }^{9}$ Atasi (1352), Syarah Majallatu al-Abkam al-'Adliyah, Hims Suriah:

10 al-Majallah, pasal 416.

"Mustofa Ahmad al-Zarqa'.op. cit. p.1032.

${ }^{12}$ Wahbah al-Zuhaily (1995), al-Mas'ulijab 'an Fili al-Gair, Damaskus: Dar al-Muktabi, Cet. 1, p.
} 
tanggung jawab akibat perbuatan yang tergolong ta'addi seperti merampas atau merusak harta orang lain. Kedua definisi tersebut juga tidak menyentuh dhaman alaqdi (ganti rugi yang muncul akibat pelanggaran akad). Pengertian dhaman seperti ini sudah barang tentu masih kurang karena tidak mengakomodasi seluruh teori dhaman yang sudah ditumuskan oleh para fuqaha'.

Adapun definisi al-Syaukani, al-Zarqa', dan al-Zuhaili sama-sama berangkat dari darar. Darar-lah jang mewajibkan ganti rugi. Berdasarkan titik tolak ini maka dhaman mencakup sesuatu yang wajib pada zimmab untuk menghilangkan darar yang muncul akibat pelanggaran pada akad (mukhalafatu aqdin), melakukan dan atau tidak melakukan perbuatan tertentu sehingga mengakibatkan mafasid. Al-Bazdawi mengisyaratkan dua macam dhaman, yaitu dhaman al-agdi fasidan kana awu jaizan yajibu bi al-tarodbi, wa dhaman al-udwan ya'tamidu awusofal 'ain ${ }^{13}$ (ganti rugi akibat pelanggaran terhadap perjanjian dalam akad fasid maupun jaiz (akad sahih) diwajibkan berdasarkan kerelaan masing-masing pihak, dan ganti rugi akibat pelanggaran tersebut mengacu pada sifat-sifat barang).

Hal yang sama juga dilakukan oleh al-Sarakhsi. Ia membedakan antara dhaman al-udwan dengan dhaman al-aqdi (ganti rugi akibat pelanggaran dengan ganti rugi berdasarkan akad). ${ }^{14}$ Indikasi perbedaan tersebut juga ditunjukkan oleh al-Suyuthi yang merinci sebab-sebab dhaman menjadi dua yaitu ta'addi dan aqdi. ${ }^{15}$ Cakupan dhaman, dengan demikian, meliputi wilayah perdata dan pidana. Sehingga ganti rugi dapat terjadi atas barang yang rusak atau manfaat barang yang hilang, atau luka fisik seseorang sehingga mengakibatkan kerugian, baik total atau sebagian.

Dari catatan tersebut dapat disimpulkan bahwa dhaman adalah tanggungan seseorang untuk memenuhi hak yang berkaitan dengan kehartabendaan, fisik, maupun perasaan seperti pencemaran nama baik. Hal ini berlaku baik darar yang muncul akibat pelanggaran seluruh dan atau sebagian perjanjian dalam akad, melakukan perbuatan (yang diharamkan) dan atau tidak melakukan perbuatan yang (diwajibkan) oleh pembuat undang-undang. Dengan demikian definisi ini mencakup makna-makna sebagai berikut:

a) Obyek wajib dhaman terletak pada zimmah (perjanjian). Kewajiban dhaman tidak akan gugur kecuali dengan memenuhi atau dibebaskan oleh pihak yang berhak menerima ganti rugi tersebut. Pihak yang dirugikan (mutadarrar) berhak mengadukan mutasabbib (penyebab kerugian) ke pengadilan agar memenuhi kewajibannya. Berbeda dengan kewajiban yang bersifat moral atau keagamaan, syari'hanya mendorong untuk memenuhinya tanpa implikasi hukuman keduniaan karena merupakan kbitab al-targib yang meliputi makrubat dan mandubat. Zimmab

${ }^{13}$ Al-Bazdawi, Ushul, hal. 31.

${ }^{1+}$ Al-Sarakhsi (1324 H), al-Mabsut, Mesir: al-Sa'adah, Jilid. XI, p.69. 


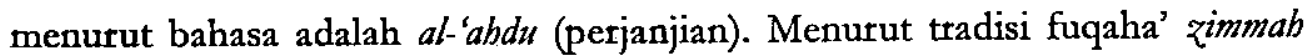
adalah suatu sifat yang menjadikan seseotang mempunyai kompetensi untuk menerima hak atau melakukan kewajiban. Ablu zimmab adalah mereka yang melakukan perjanjian di mana dengan perjanjian itu mereka memiliki hak dan kewajiban.

b) Kewajiban atas dasat dhaman berbeda dengan kewajiban atas dasar 'uqubah, baik pada karakter maupun tujuannya. Dhaman ditetapkan untuk melindungi hak-hak individu. Sedangkan 'uqubab ditetapkan karena adanya unsut pelanggaran terhadap hak-hak Allah SWT. Kewajiban pada dbaman bertujuan untuk mengganti atau menutupi (al-jabru) kerugian pada korban. Sementara 'uqubab ditetapkan untuk menghukum pelaku kejahatan agat jera dan tidak melakukan perbuatan itu lagi (al-zajru). Jadi tujuan yang berorientasi pada al-jabru disebut dhaman. Sedangkan tujuan yang berorientasi pada al-zajru disebut "uqubah.

c) Sebab-sebab dhaman adalah adanya unsur ta'addi, yaitu melakukan perbuatan terlarang dan atau tidak melakukan kewajiban menurut hukum. Ta'addi dapat terjadi karena melanggar perjanjian dalam akad yang semestinya harus dipenuhi. Misalnya, penerima titipan barang (al-muda)'tidak memelihara barang sebagaimana mestinya, seorang al-ajir (buruh upahan, orang sewaan) dangan al-mustajïr (penyewa) sama-sama tidak komitmen terhadap akad yang mereka sepakati. Ta'addi juga dapat terjadi karena melanggar hukum syariah (mukbalafatu abkâm syari'ab) seperti pada kasus perusakan barang( al-itlâff), perampasan (al-gasb), maupun kelalaian atau penyia-nyiaan barang secara sengaja (al-ihmâl).

d) Ta'addi yang mewajibkan dhaman benar-benar menimbulkan darar (kerugian). Jika tidak menimbulkan kerugian, maka tidak ada dhaman, karena secara faktual tidak ada darar yang harus digantirugikan. Itulah sebabnya jika seorang pengendara yang lalai menabrak barang orang lain tetapi tidak menimbulkan kerusakan, tidak wajib memberikan dhaman. Namun demikian, terdapat suatu perbuatan dengan sendirinya mewajibkan dhaman seperti al-gasbu (perampasan). Menurut jumhur ulama, pelaku perampasan harus mengganti manfaat barang selama berada dalam penguasaannya walaupun tidak difungsikan. Pendapat ini berdasarkan asumsi bahwa kerugian selalu terjadi pada kasus-kasus perampasan. Kerugian atau darar juga akan dialami oleh orang-orang yang dibatasi kebebasannya oleh penguasa atau seseorang yang ditahan secara ilegal menurut fuqaha' Hanabilah. Pendapat ini memperkuat kaidah bahwa al-dharar syarthun liwujubi dhaman (kerugian adalah syarat terhadap keharusan ganti rugi).

e) Antara ta'addi (pelanggaran) dengan darar (kerugian) harus memiliki hubungan kausalitas. Artinya, darar dapat dinisbatkan kepada pelaku pelanggaran secara langsung. Jika darar dinisbatkan kepada sebab-sebab lain, bukan perbuatan pelaku (muta'addi) sendiri, maka dbaman tidak dapat diberlakukan, karena seseorang tidak 
dapat dibebani tanggung jawab atas akibat perbuatan orang lain. Kaidah syariah mengenai masalah ini adalah:

$$
\text { لا تزر وازرة وزر أخرىى ؛ لا يؤاخذ أحل بيريرة غيره . }
$$

f) Darar harus bersifat umum sesuai dengan keumuman hadis Nabi: laa dbarara wa laa dbirara (tidak boleh merugikan diri sendiri dan merugikan orang lain). Tingkat darar diukur berdasarkan 'urf (kebiasaan) yang betlaku. Hal ini sejalan dengan kaidah ushul: yajibu hamlu al-laffi 'ala ma'nabu al-mubaddad fi as-syar'i in wujida, wa illa wajaba bamlubu 'ala ma'nabu al-urfi (suatu keharusan membawa kata kepada maknanya yang definitif secara syara' jika ditemukan, tetapi kalau tidak ada, maka dialihkan kepada makna definitif berdasarkan 'urf). Karena syari' tidak menetapkan makna darar, sehingga ukurannya, baik kualitas maupun kuantitas, mengacu pada 'uff. Dengan demikian, darar yang diganti rugi berkaitan dengan harta benda, manfaat harta benda, jiwa, dan hak-hak yang berkaitan dengan kehartabendaan jika selaras dengan 'urf yang berlaku di tengah masyarakat.

g) Kualitas dan kuantitas dhaman harus seimbang dengan darar. Hal ini sejalan dengan filosofi dhaman, yaitu untuk mengganti dan menutupi kerugian yang diderita pihak korban, bukan membuat pelakunya agar menjadi jera. Kendati demikian, tujuan ini selalu ada dalam berbagai sanksi, walau hanya bersifat konvensional.

Penetapan makna demikian sejalan dengan makna dbaman ${ }^{16}$ secara bahasa, yakni ganti rugi. Maksud ganti rugi yaitu penggantian kerugian yang dialami seseorang. Pemaknaan seperti ini juga terdapat dalam KUH Perdata pasal 1244 dan 1248.

Dari sini perlu dimengerti bahwa dhaman dapat diterapkan dalam berbagai bidang muamalah, terutama menyangkut jaminan harta benda dan nyawa manusia. Maka dari itu, tidak mengherankan bila al-Mawardi mengatakan bahwa dhaman dalam

${ }^{15} \mathrm{Jalaluddin}$ Al-Suyuthi (1994), al-Aybbab wa al-Naza'ir, Beirut: Muassasah al-Kutub al-Saqofiyah, Cet. 1,p. 362 .

${ }^{16}$ Dasar legalitas dhaman antara lain ayat al-Qư'an: famani tadâ 'alaikumfa'tadâ 'alaihi bimist mâ îtadâ

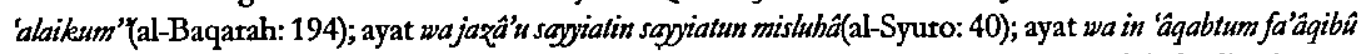
bimisli mâ "äqibtum bibi" (al-Nahl:-126). Adapun di dalam al-Sunnah disebutkan, antara lain hadis, riwayat Anas berkata: Ahdat ba'dhu apvajin nabi SW ilaibi tha'aman fi qush'atin, fadharabat al-qus'ata biyadiha, fa algat mâ fibâ, faqâla an-nabi SW: tha'amun bitha'amin, wa inâun bi inâin (Riwayat Tirmizi). Juga hadis yang cukup populer ' Alâ al-yadi mâ akhazat hattâ tuaddihi (Riwayat Ahmad). Hadis lainnya, Inna dimâakum wa amvâlakum' ' alaikum haromun kaburmati yaumikum haza, fi sjabrikum haza, fi baladikum häza (BukhariMuslim). Ibn Hazam juga mengatakan bahwa yang sahih adalah bahwa harta yang diharamkan tidak ada kewajiban seseotang untuk memberikan ganti rugi terhadapnya, baik di dalam nas ataupun ijma'. Hadis lain yang paling populer adalah lâ dharara wa lâ dhirâra. Imam al-Kasani betkata, "Diwajibkan ganti rugi pada kasus perampasan dan perusakan (al-gashbu wa al-itlaf), karena semua itu mengandung unsur perbuatan itidâ' dan idrâr." (Badầi, hal. VII/165). 
pendayagunaan harta benda, tanggungan dalam masalah diyat, jaminan terhadap kekayaan, jaminan terhadap jiwa, dan jaminan terhadap beberapa perserikatan adalah hal yang lumrah terjadi di masyarakat. Dengan demikian, dhaman dapat diterapkan juga dalam masalah jual beli, pinjam meminjam, titipan ( $a l$-wadi'ab), jaminan ( $r a b n$ ), kerja patungan (girad/mudbarabab), barang temuan (lugathab), peradilan (qada), hukuman terhadap pembunuhan (qisas), perampasan (gasab), pencutian, dan sebagainya.

\section{Sebab-Sebab Dhaman ${ }^{17}$}

Kaum fuqaha' tidak mendiskusikan rukun dhaman secara sistematis dan terpadu seperti yang dilakukan oleh ahli hukum. Mereka membahasnya secara sporadis di berbagai tempat, antara lain di dalam kitab-kitab al-furu', kaidah-kaidah fiqh, dan kitab ushul al-fiqh. Walau begitu, rukun dhaman sudah tergambar di dalam pemikiran mereka ketika mendiskusikan berbagai kasus hukum fiqh. Dari berbagai konstruksi dan fatwa hukum dalam karya-karya figh, dapat disimpulkan bahwa rukun dhaman adalah khatha', dharar, dan sababiyah.

Perbuatan-perbuatan hukum yang mewajibkan dhaman hampir tidak terbatas jumlahnya. Tetapi secara akumulatif perbuatan-perbuatan tersebut dapat disebut perbuatan gair masyru'ab, atau akbtha' atau ta'ddiyat (delicts, torts, wrongs). Namun untuk memudahkan sistem pertanggungjawaban tethadap akibat perbuatan, maka para ahli hukum pertama-tama melakukan pembagian terhadap perbuatan prespektif motif dan tujuan pelaku menjadi: akbtha' 'amdiyah (intekntional torts) dan akhtha' taqshiriyab

${ }^{17}$ Seseorang tidak dapat dibebankan ganti rugi kecuali memenuhi dua rukun, yaitu: al-itida'dan aldarâr. Al-i'tidâ' adalah melampaui batas yang menurut para fưqaha' mengandung unsur kezaliman, rasa permusuhan, dan melampaui hak. Kriterianya adalah menyimpang dari perilaku normal. Adapun sebabsebab dhaman ada tiga, yaitu agad, yad, dan itlaf. Dbaman pada agad dapat terjadi ketika ada pihak yang melakukan interpretasi terhadap ketentuan eksplisit dari redaksi perjanjian atau makna implisitnya sesuai dengan keadaan dan situasi (al-urf atau al-âdab) yang betlaku. Sedangkan wadb'u al-yad dapat menjadi sumber ganti rugi baik itu al-yad mu'tamanab maupun bukan mu'tamanab. Yad al-mu'tamanah seperti yad alwâdi'dan al-mudhârib, al-âmil al-musâqi, al-ajir al-khâs, al-washi 'ala mâl al-yatim, hakim dan al-qadhi 'ala sundug al-aitâm, dan lain-lain. Mereka ini jika melakukan ta'addi (personal abuse case) atau taqshir dibebani/dikenakan ganti rugi. Namun jika tidak ada unsur ta'addi atau taqshir tidak dapat dibebankan ganti rugi karena mereka tergolong al-aydi al-amânab (tangan-tangan amanah). Adapun al-yad gairu al-mu'tamanah yang melakukan sesuatu terhadap harta orang lain tanpa izin dari pemilik seperti pencuri dan perampas, atau dengan seizin pemilik seperti al-yad al-bâ'i' terhadap barang yang dijual sebelum serah terima, atau al-musytari setelah serah terima barang, dan penyewa hewan tunggangan atau semisalnya jika melakukan ta'addi terhadap syarat-syaraf yang sudah ditentukan atau ketentuan yang sudah biasa berlaku. Mereka ini wajib memberikan ganti rugi terhadap kerusakan barang pada saat berada di tangannya, apapun penyebab kerusakan sekalipun terpaksa seperti bencana alam dan lainnya. Adapun al-itlâf menjadi sebab ganti rugi baik langsung maupun hanya sebagai penyebab. Itlâfbiasanya diartikan mendisfungsikan barang. al-Itlaf dibagi dua yaitu al-itlaf al-mubasyir (perusakan langsung), dan al-itlaf bi al-tasabbub (perusakan tidak langsung). (Pembahasan tuntas dapat dilihat dalam al-Kasani, al-Badâ'i' dan dalam Majallatu al-Ahkâm al-Adliyah pasal 887-888. 
atau al-ibmal (negligence).

Di dalam figh, al-akbtha' gair al-amdiyah dibagi menjadi dua macam yaitu al$k h a t h a '$ dan mâ jarâ majrâbu. Suatu perbuatan yang menjadi tujuan pelaku, namun tidak menghendaki akibatnya disebut al-khatha'. Sedangkan suatu perbuatan dan akibatnya sama-sama tidak dikehendaki oleh pelaku disebut mâ jarâ majrâ al-khatba'. Yang pasti khatha' 'amdi sangat berbahaya sehingga di dalam hukum Barat-dengan mengacu kepada istilah hukum Perancis - disebut al-khatha' lâ yagtafiru (kesalahan yang tidak dimaafkan). ${ }^{18}$

Perbuatan-perbuatan mewajibkan dhaman, kata al-Qurafi ${ }^{19}$ adalah dilakukan secara langsung oleh pelaku (al-'udwan bi al-mubâsyir), kemudian karena perbuatannya tersebut mengakibatkan kerusakan (al-tasabbub li al-itlâf) pada harta benda misalnya. Singkatnya, sebab-sebab dhaman adalah al-mubasyir, al-tasabbub, dan al-itlaf. Ketusakan ini tidak mesti menjadi tujuan dari pelaku (qashdu al-fa'il). Karena masing-masing orang bertanggung jawab atas akibat perbuatannya. Prinsip ini sesuai dengan kaidah fiqh:

$$
\text { الرضا بالشيء رضا .با يتولد عنه }
$$

Adapun kesengajaan ( $a l$-amd) yang mengakibatkan dararatau kesengajaan untuk melakukan perbuatan namun tidak mengakibatkan darar, tidak menjadi syarat dalam penetapan dhaman. Karena dhaman berkaitan dengan perbuatan hukum dalam lingkup kbatha' atau 'udwan bukan pada tujuan perbuatan atau niat pelaku:

Namun demikian, khatha'yang mengharuskan dhaman dibedakan dengan khata' yang mengharuskan 'uqubab serta khatha' al-akblaqi (kesalahan secara moral) yang hanya berimplikasi pada dosa. Orang tidur menurut teori ini tidak salah secara motal dan juga tidak berdosa. Dengan demikian kalau dia terbolak balik atau jatuh menimpa sesuatu sehingga menimbulkan kerusakan, dia wajib melakukan dhaman, tetapi secara etis relegius dia tidak berdosa.

Dhaman tidak terkait dengan al-qasdu dan al-niat. Pendapat ini berdasarkan ijma'. Karena ijma'-lah yang mewajibkan dhaman bagi seorang anak yang belum dewasa (al-sabiyz), orang gila (al-majnun), orang pelupa (al-nasi), orang tidut (al-naim) dan orang lalai (al-gafil). Dhaman semata-mata terkait dengan al-asbab (adanya sebab akibat). Atau dengan meminjam istilah imam al-Gazali bahwa al-abliyab (cakap hukum) yang menjadi syarat dalam menetapkan dhaman adalah abliyatu al-mujub yaitu seseorang dianggap cakap hukum untuk menerima hak, bukan abliyat al-ada' di mana seseorang dianggap cakap melakukan petbuatan hukum.

Meski sangat jelas bahwa khatha', ihmal, dan taqshirmenjadi syarat wajib dhaman, namun tim penyusun al-Majallab al-Abkam al-'Adliyah sepertinya mengabaikan prinsipprinsip umum dhaman. Hal ini terbukti bahwa mereka menetapkan unsur kesengajaan

${ }^{18}$ Muhammad Siraj. op. cit..p. 15. 
(ta'ammud) sebagai syarat dhaman seperti disebutkan dalam pasal 92, al-mubasyir dbiman wa lam yuta'ammad. Sedangkan dalam pasal 93 disebutkan: al mutasabbib la yudhmanu illab bi at ta'ammud.

Kemungkinan ada dua faktor yang menyebabkan kekeliruan tersebut. Pertama, mengikuti kesalahan yang terdapat dalam karya-karya klasik terutama kitab al-Asybâb karya Ibn Nujaim yang menyebutkan:

$$
\text { المباشر ضامن وإن لم يتعمد و المتسبب لا، إلا إذا كان متعمدا }
$$

Kedua, ada kemungkinan mengikuti jejak sebagian fuqaha' Hanafiyah generasi awal yang keliru memahami dan menafsirkan mazhab Abu Hanifah yang menetapkan bahwa penyebab kerusakan dibebani ganti rugi (tadbmin mutasabbib). Imam mazhab sendiri tidak melihat tadhmin mutasabbib kecuali ada unsur kesalahan (al-khatba') yang mirip dengan kesengajaan atau suatu kesalahan yang sangat berlebihan sehingga mendekati atau setidaknya mitip dengan kesengajaan.

Terlepas dari apakah ini merupakan kesalahan ilmiah atau kesalahan teknis pengetikan, namun yang pasti kaidah tersebut harus dibaca dalam konteks: anna al mutasabbib la yudbman (illa idza kana muta'addiyan) $\mathrm{Hal}$ ini sesuai dengan kaidah yang ada di dalam Majma' Dhamanat. ${ }^{20}$

Kaum fuqaha' tidak menetapkan syarat bahwa orang yang menyebabkan (mutasabbib) kerugian harus sudah mumayyiz, atau memiliki al-idrak (pemahaman dan pengetahuan) terhadap kewajiban dhaman. Sehingga seorang anak yang masih usia mumayyiz atau belum, wajib dikenakan dhaman jika melakukan perbuatan yang mengakibatkan kerugian pada orang lan. Demikian pula al-ma'tub (orang idiot) dan al-majnun (gila). Karena tujuan dari dhaman adalah ganti rugi dengan mal, yang pembayarannya dapat diwakilkan kepada pihak lain.

Hadis tentang rufi'a 'an ummati al khatha'a wa an nisyana (diampuni umatku suatu perbuatan karena kelalaian dan kealpaan) tidak menafikan hukum dhaman ketika terjadi al-tagshir (kecerobohan) dan al-ibmal (kelalaian). Karena yang diampuni adalah dosa atau hukuman pidana, bukan hukuman dhaman. Hal inilah yang menjadi perhatian para fuqaha'. Seorang faqih Sadru al-Syari'ah menyebutkan bahwa al-khatha' adalah apabila seseorang mengerjakan suatu perbuatan, tetapi perbuatan itu sendiri tidak diniati secara sempurna. Misalnya, orang menembak hewan buruan namun pelurunya nyasar mengenai seseorang sehingga tewas. Di sini terdapat niat atau alqasdu yang tidak sempurna. Sehubungan dengan ini si pemburu tidak dapat dikenakan qisas karena hukuman ini diperuntukkan bagi pelaku pidana penuh. Atas dasar ini, ia tidak dapat dikenakan kepada orang ma'zur (orang yang dimaafkan). Namun 'uzur

${ }^{19}$ Ahmad Ibn Idris al-Qurafi (1998), al-Furug fi Anvar al-Buruq fi Anvai al-Furuq, Mansyurat Muhammad Ali Baidhun, Beirut: Dar al-Kutub al-ilmiyah, Cet. I. Jilid. II, P. 207.

${ }^{20}$ al-Bagdadi $(1388 \mathrm{H}$ ), Majma' al-D hamanat, Mesir: al-Khairiyah, p. 57. 
ini terkait dengan hak-hak hamba sehingga kategori dhaman-nya adalah dhaman al'udwan.

D. Macam-macam Khatha' dan Darar

Secara teoritis khata' dapat berupa meninggalkan kewajiban yang ditetapkan oleh syariah. Misalnya, seorang ibu meninggalkan anaknya sehingga jatuh. Khata' juga dapat dalam bentuk melakukan perbuatan yang haram. Misalnya, memberikan kesaksian palsu, merampas harta orang lain, merusak atau menyebabkan rusaknya harta.

Dhaman tidak akan berlaku kalau tidak ada unsur khatha'. Dan khatha' tidak akan ada kalau seseorang melakukan suatu perbuatan yang diijinkan oleh syariah (hukum).

Sedangkan darar sendiri ada tiga macam, yaitu darar yang berkaitan dengan kehartabendaan; darar yang berkaitan dengan fisik; dan darar yang berkaitan dengan kehormatan dan nama baik seseorang atau lembaga. Yang terakhir ini disebut dengan darar adabi. Menjaga dan melindungi kehormatan dan nama baik masuk dalam kategori al-masalib al-daruriyah atau kemaslahatan primer.

Namun dari aspek lain, darar dibagi menjadi dua, yaitu, pertama, darar al-yasir (kerugian ringan). Para fuqaha' pada umumnya berpendapat tidak ada dhaman terhadap darar ini. Menurut hemat penulis, permasalahan ganti rugi terhadap darar yasir bersifat kondisional. Kedua, darar fakbisy (kerugian berat).

Beberapa kaidah yang berkaitan dengan darar adalah:

$$
\begin{aligned}
& \text { يتحمل الضرر الخاص لدفع الضرر العام ، الضصرر الأشتد يزال بالضرر الأنحف ، إذا تعارض مفسدتان روعي }
\end{aligned}
$$

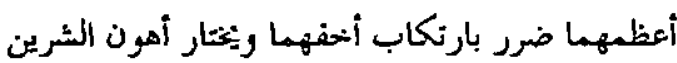

Sementara kerusakan terhadap harta benda (darar maliyah) dapat digolongkan menjadi kerusakan terhadap benda bergerak (manqulat), benda tidak bergerak ("iqarat), dan jasa (al-manafi). ${ }^{21}$

Para fuqaha' sepakat atas dhaman terhadap kerusakan benda bergerak (karena metampas barang, merusak atau menguranginya, mengubah bentuk barang atau mengeksploitasi. pemanfaatannya). Sehubungan dengan dhaman barang-barang bergerak terdapat dua syarat:

Pertama, maliyatu al-manqul (barang bergerak itu betul-betul harta secara syara'). Al-manqulat (bentuk jamak dari al-manqul) yang kehartaannya tidak diakui oleh syara' tidak dapat dilakukan ganti rugi-terhadapnya. Itulah sebabnya tidak ada dhaman dengan merusak bangkai, kulit bangkai, darah dan lain-lain yang pemanfaatannya dilarang oleh syara'. Juga yang tidak dapat dilakukan dhaman tethadapnya adalah al-

${ }^{21}$ Lihat Ibrahim Fadil al-Dabbo (1997), Dhaman al-Manafi' Dirasah Mugaranah fi al-Fiqh al-islami wa al-Qanun al-Madani, Amman, Beirut: Dar al-Bayariq, Dar 'Ammar, Cet. I, p. 
mubahat al-âmmab (hak-hak umum) yaitu al-kala' (rumput), al-ma' (air) dan al-nâr (api). Itulah sebabnya jika ada seseorang menimba sumur orang lain sampai kering, tidak dikenakan dhaman. Sebab pemilik sumur, bukan berarti memiliki ait, berbeda kalau merampas air dari wadah yang lain. Hukum al-kala' (kecuali kalau dipelihara dan ditanam), dan al-nâr sama dengan hukum al-mâ'.

Kedua, tuqawnimu al-manqul (barang tersebut mengandung nilai ekonomis). alTagannum menurut Ibn Nujaim dapat ditetapkan berdasarkan dua hal, yaitu adanya unsur kehartaan (al-maliyab) dalam suatu barang, dan barang tersebut boleh dimanfaatkan menurut syara'.

Adapun barang-barang tetap (al-igârât, immovable property), para fuqaha' bersepakat wajibnya dhaman terhadapnya apabila merusak keseluruhan, sebagian atau merugikan pemiliknya. Berbeda dengan manâfi' terdapat perbedaan pendapat yang berkaitan dengan dhaman terhadapnya. Perbedaan ini sebagai konsekuensi dari silang pendapat yang terjadi antara fuqaha tentang status kehartaan al-manafi' (maliyatu al-manafi'). Fuqaha' Hanafiyah terutama generasi awal tidak menetapkan dhaman terhadap al-manafi', karena wujudnya yang absttak, sehingga ia tidak termasuk harta. Pendapat ini berbeda dengan pendapat mayoritas fuqaha dari berbagai mazhab, termasuk Syiah Imamiyah, menurut mereka dhaman terhadap al-manafi' sesuatu yang wajib.

Argumentasi fugaha' Ahnaf antara lain bahwa al-manafi' tidak mengandung nilai ekonomis. Statusnya sama dengan khamar dan bangkai. Artinya, al-itlâf tidak tergambar pada al-manâfi' mengingat sifatnya yang abstrak. Pendapat ini oleh fuqaha' Hanafiyah generasi mutaakbkhirin dianggap lemah, sehingga mereka mengevaluasi pendapat tersebut dan mengemukakan bahwa al-manâfi' adalah bagian dari al-mal (harta).

Adapun darar badaniyah meliputi jiwa, anggota badan, atau hilangnya fungsi salah satu anggota badan. Misalnya, hilangnya pendengaran dan penglihatan. Terhadap semua kasus yang berkaitan dengan kerugian fisik seluruh atau sebagiannya, menurut para fuqaha' betlaku hukum dbaman terhadapnya.

\section{E. Menakar Ganti Rugi}

Tujuan dari pada dhaman adalah untuk memberikan ganti rugi pada korban dan menghilangkan kerugian yang diderita (raf'u al-darar wa izalatuba). Hal ini mencakup dua hal. Pertama ganti rugi terhadap kerugian yang berhubungan dengan jiwa, kehormatan, dan nama baik seseorang. Kedua, ganti rugi terhadap kerugian yang berkaitan dengan harta benda.

Ganti rugi terhadap kerugian yang berhubungan dengan jiwa disebut jawabir al-dharar al-badaniyab mencakup kehilangan jiwa, kehilangan anggota badan, atau fungsi keduanya. Jawabir model ini oleh para fuqaha' disebut dengan diyat (ganti rugi 
pembunuhan), ursy al-muqaddarah wa gairu al-muqaddarab (denda luka yang sudah ditetapkan di dalam nas). Ganti rugi model ini sering disebut bukumatu 'adl karena ukuran kualitas dan kuantitasnya diserahkan kepada otoritas peradilan yang adil.

Adapun ganti rugi yang betkaitan dengan hatta (jawabir al-darar al-maliyah) seperti perampasan, perusakan terhadaip barang atau manfaatnya mencakup dua hal yaitu:

1. Jawabir naqdiyah yaitu ganti rugi dengan mengembalikan nilai jual barang (al-qimab). 2. Jawabir 'ainiyah, yaitu ganti rugi dengan mengembalikan barang itu sendiri, atau menggantinya dengan barang yang sama dalam kasus-kasus perampasan dan penguasaan terhadap harta orang lain secara tidak legal.

Adapun hitungan atau perkiraan (al-tagdir) ganti rugi bisa mengacu pada beberapa model berikut. Pertama, perhitungan ganti rugi berdasarkan kesepakatan (al-tagdir al-ittifagi). Kedua, penggantian ganti rugi yang dilakukan oleh hakim (altaqdir al-qadai) yang mengacu pada ijtihad dan pendapatnya. Dan, ketiga, penghitungan ganti rugi sesuai dengan yang ditetapkan oleh pembuat undang-undang (al-tagdir alsyar'z).

Hitungan dan perkiraan ganti rugi tersebut berasaskan pada beberapa hal.

1. Ganti rugi tidak dimaksudkan untuk memperkaya pihak yang dirugikan, menolongnya, atau memberikan tabarru' terhadapnya. Namun, dimaksudkan untuk mengembalikan keadaannya seperti sebelum terjadi kerugian-dengan catatan jika hal itu memungkinkan.

2. Ganti rugi dibebankan kepada pihak yang mengakibatkan darar secara langsung. Adapun darar tidak langsung yang tidak dapat dinisbatkan kepada perbuatan muta'addi tidak dapat dikenakan ganti rugi.

3. Hitungan dan petkitaan ganti rugi disesuaikan dengan tingkat darar yang ada, tidak lebih dan juga tidak kurang. Menyimpang dari prinsip ini dikategorikan "aklu amwalinnas bi al-bathil (makan harta orang lain secara batil). Kecuali dalam kasus di mana tingkat ta'addi-nya sangat tinggi, ganti rugi perlu dilipatgandakan agar pelaku menjadi jera.

Bila dilihat dari berat ringannya ganti rugi, para fuqaha' membaginya menjadi dua macam. Pertama,kerugian tingan (jawabir mukhafffafab) yang diukur berdasarkan tingkat kerugian (darar) yang diderita pihak korban. Kedua, kerugian berat (jawabir mughallazab). Jawabir mukhaf-fafah terlihat pada kasus-kasus dalam kategori khatha'. Sedangkan jawabir mugallazab terlihat pada kasus-kasus syibhu al-amad (perbuatan semi sengaja). Pelipatgandaan ganti rugi dikenakan kepada mereka yang mengambil harta orang lain dan membelanjakannya untuk memperkaya diri sendiri. Tujuan dari tagliz (pemberatan dengan pelipatgandaan kerugian) adalah zijru al-muta'addi (membuat pelaku agat menjadi jeta) tidak mengulangi perbuatan yang melawan hukum. Kendati demikian perbedaan antara al-uqubab dengan dhaman selalu ada, setidaknya dapat 
diamati sebagai berikut:

1. Al-qatl syibbu al-amad (pembunuhan semi sengaja). Sisi tagliz dalam kasus pembunuhan ini adalah tingginya umur unta yang dijadikan sebagai diyat wajib. Hal ini berdasarkan hadis riwayat Abdullah Ibn Amr bahwa Rasulullah bersabda ${ }^{22}$ :

آلا إن في قتيل عمد المنطاً" قتيل السوط والعصا، مانة من الإبل، منها أربعون نحلفة في بطونها أرلادها

(bahwa dalam kasus pembunuhan semi sengaja yaitu pembunuhan dengan cemeti dan tongkat, dendanya seratus unta, 40 di antaranya sedang mengandung). Hadis yang searti dengan itu juga diriwayatkan oleh Amr Ibn Syu'aib bahwa seseorang yang bernama Qatadah melempar anaknya dengan pedang sampai tewas. Karena itu, diyat yang dibebankan kepadanya adalah 30 ekor unta kategori higgah (umur 3 tahun masuk tahun ke 4); 30 unta lagi kategori jiz'ab (umur 4 tahun masuk tahun ke 5), dan 30 ekor lagi kategori khilfah (unta yang sedang mengandung).

2. Mengambil harta orang lain yang sulit diletakkan pada wadah tertentu atau dijaga sepanjang waktu. Diriwayatkan dari Amr Ibn Syu'aib dari ayah dan neneknya berkata: "Rasulullah pernah ditanya tentang buah-buahan yang masih menggantung di pohonnya. Lalu beliau bersabda:23

$$
\begin{aligned}
& \text { من أصاب منه بفيه من ذي حاجة غير متخد نحبنة فلا شيح عليه . ومن خحرج بشيى فعليه غرامة }
\end{aligned}
$$

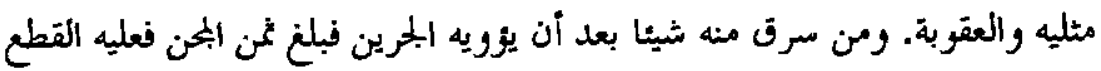

Dengan demikian jawabir mugallazab tidak hanya pada luka-luka fisik, melainkan juga pada kerugian harta dalam situsi-situasi yang memerlukan "pemberatan terdakwa" seperi ingin memperkaya diri dengan cara merugikan orang - lain. Fenomena ini sekaligus memberikan keleluasaan hakim dalam menghitung dan mempetkirakan kualitas dan kuantitas ganti rugi.

\section{F. Prinsip Umum Penetapan Ganti Rugi}

Penggunaan istilah al-jabr oleh para fuqaha' dalam konteks dhaman yang dihubungkan dengan dararmasih mengandung ambiguitas. Katena makna darar sangat beragam mengikuti konteksnya. Misalnya, al-jibr al-kamil (ganti rugi penuh) bertujuan untuk menetapkan ganti rugi yang harus ditanggung oleh pihak pelaku (al-mutadarrir): Darar dalam konteks ini mencakup darar maliyab, darar badaniyab, dan darar adabiyah. Standarisasi jibru al-kamilbersifat kondisional, tergantung pengadilan dan usaha cerdas hakim. Karena betapa sulitnya mengukur rasa sakit yang bersifat psikis dibandingkan kerugian lain yang bersifat material. Dengan kata lain, rasa keadilan yang didambakan oleh para pencari keadilan sangat ditentukan oleh sikap, kecermatan, dan keadilan

$\cong$ Ali al-Syaukani, op. cit. Jilid. VII. p. 167.

${ }^{23}$ Lihat juga beberapa hadis lain yang semakna dalam Nail al-Authar oleh Ali al-Syaukani, op. cit. Jilid, VII, p. 301. 
hakim itu sendiri.

Dalam menetapkan ganti rugi, setidaknya harus didasarkan pada empat prinsip. Pertama, prinsip al-yusr (memudahkan) dalam menghitung dan mengukur ganti rugi tersebut untuk menghindari proses dan prosudur yang panjang di pengadilan agar para pencari keadilan tidak terlalu lama menunggu haknya.

Kedua, konsisten. Artinya, terdapat keseragaman kualitas dan kuantitas ganti rugi dalam kasus yang sama pula.

Ketiga, menyamakan (al-musawat) antara semua penduduk dalam menerima ganti rugi. Misalnya, jangan sampai ada pembedaan antara petani dengan pengusaha untuk ganti rugi kasus yang sama, karena prinsip dalam menetapkan darar bukan mempertimbangkan strata sosial atau kemampuan finansial.

Dan keempat, harus terlebih dahulu mengidentifikasi dan menetapkan tingkat keterlibatan para pelaku. Karena hal ini akan menentukan kualitas ganti rugi yang akan dibebankan kepada mereka.

\section{G. Prinsip al-Misli dalam Menetapkan Ganti rugi}

Prinsip persamaan (mabda' al-misliyab) dalam ganti rugi ditetapkan berdasarkan nas syariah antara lain firman Allah wajazau saiatin saiatun misluha. Disebut dengan istilah al-uqubah atau al-jaza' semata-mata dalam konteks al-musyakalab/al-mumasalab (persamaan), dan juga untuk mengingatkan si pelaku agat menjadi jera. Prinsip almumasalab juga diperkuat oleh ayat fa mani'tada 'alaikum fa'tadu 'alabi bi misli ma i'tada 'alaikum. Untuk membantu kita dalam menafsirkan ayat ini, perlu kiranya mengutip perkataan al-Zaila'i, seorang fuqaha' Hanafi, wa dhaman al-udawan masyrutbun bi al-mumasalab bi al-nassi wa al-ijma'. Wasummiya dhaman al-muqabil itidaan bi thariq al-muqabalab li fili al-itida' awn al-idhrar majazan la haqiqatan, li anna al-majazat awn dbaman la yakun saiyiab wala ta'ddiyan. ${ }^{2 f}$ Inti dari pernyataan al-Zaila'i bahwa ganti rugi pelanggaran disyaratkan harus sama berdasarkan nas dan ijma', sedangkan penamaan dhaman berdasarkan pelanggaran dalam konteks majazi, bukan pada makna hakikinya, karena ganti rugi menurut makna majazinya bukanlah sesuatu yang buruk atau merupakan suatu pelanggaran.

Menghitung ganti rugi mengacu pada kaidah kesepadanan (al-misli) dengan $\therefore$ 'mempertimbangkan metode syari' dalam menetapkan al-misli, al-qimab dan ujratu almisli terhadap ganti rugi al-mal. Namun, manakala kaidah al-misli sulit diterapkan dalam kasus-kasus luka fisik (al-isabat al-badaniyab), karena luka fisik, sesungguhnya, tidak mungkin sepadan dengan ganti rugi dalam bentuk uang, maka syari'menetapkan ukuran-ukuran tertentu yang dapat direalisasikan yaitu al-jawabir al-muqaddarab

${ }^{24}$ Usman Ibn Ali al-Zaila'i (1990), Tabyin al-baqoiq Syarh Kanzu al-Dagaiq, Kairo: Dar al-Kitab alIslami, Cet. II, Jilid. V, p. 223. 
misalnya diyat (denda pembunuhan), al-urusy (denda luka), al-aqilab (denda pembunuhan kolektif), dan lain-lain. Hal ini kemudian oleh para fuqaha' disebut almumasalab al-bukmiyab.

\section{H. Pencemaran Nama Baik (iza' al-muslim fi sum'atihi)}

Untuk melindungi kehormatan seseorang, syariah memulai dari masalah yang sederhana. Misalnya, larangan menuduh seseorang melakukan zina (al-garf), larangan saling mencela dan memberi julukan jelek (al-tanabuq bi al-alqaf) atau menafikan keturunan (nafyu al-nasab). Hal ini sesuai surat al-Hujarat ayat 11-12. Demikian pula dalam Surat al-Nur ayat 4-5. Sedang di dalam hadis disebutkan, al-muslim man salimal muslimun min lisanibi wayadib (seseorang baru dikatakan muslim apabila menyelamatkan umat Islam dari gangguan ucapan dan prilakunya).

Para fuqaha' kemudian merumuskan masalah pencemaran nama baik dalam bingkai al-magasid al-khamsah li al-syariah (lima kemaslahatan), yaitu menjaga agama, jiwa, moral, akal, dan harta. Hanya saja, para fuqaha' lebih banyak fokus pada hal-

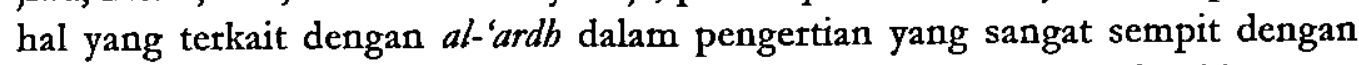
menjelaskan hukuman pelaku zina, hukuman bagi penuduh berbuat zina. Tegasnya, para fuqaha' lebih asyik menjelaskan hukum-hukum yang betkaitan dengan zina (alqaif), atau hukum lain yang berkaitan dengan kehormatan keluarga.

Al-Qur'an mengharamkan apa pun bentuk petbuatan yang menyentuh kehormatan muslim. Dalam surat al-Nur ayat 4 dan 5 , al-Qur'an mengharamkan qaरf, zina, dan hukumannya. Sementara dalam ayat 11 dan 12 Surat al-Hujarat mengisyaratkan berbagai bentuk pelanggaran yang menyentuh kehormatan dalam pengertian yang lebih luas. Misalnya sukbriyah (pengejekan), al-lam $z$ (mencela dan mengkritik dengan bahasa yang tidak etis), tanabuz bi al-qaaf (saling mencela dengan memberi julukan jelek), tajassus (memata-matai) dan al-gibab (umpatan).

Betapapun terbatasnya konsep perlindungan nama baik yang telah dirumuskan para fuqaha', namun dapat diidentifikasi menjadi pelanggaran (al-ta'addiyat) terhadap nama baik seseorang yang meliputi tuduhan melakukan zina dan tuduhan terhadap selain zina yang dapat mengakibatkan pencemaran nama baik.

Oleh katena itu fungsi faqih termasuk hakim dalam hal ini adalah melakukan istimbath hukum sekaligus mengembangkan konsep perlindungan terhadap kehormatan. Tegasnya, mereka harus mewujudkan konsep tersebut berdasarkan keumuman konsep syariah dan maqasid-nya.

\section{Hal-bal yang Menafikan Dhaman}

Pada prinsipnya dhaman dibetlakukan kepada siapapun yang menyebabkan kerugian pihak lain. Namun demikian, dhaman juga tidak dapat diberlakukan kalau terdapat halangan (al-mawani) atau alasan pembenar, antara lain:

a) Pemusnahan barang secara legal. Misalnya, khamar atau barang-barang sejenis 
tidak dapat diberlakukan ganti rugi terhadap muslim baik pribadi mapun kolektif. Karena khamar dan babi adalah harta yang pemanfaatannya dilarang oleh syariah (mal gairu mutaqanvim). Memusnahkan harta jenis ini termasuk suatu kewajiban syariah. Pendapat ini dikemukakan oleh mayoritas ulama. Hanya saja ulama Syafi'iyah dan Hanabilah menambahkan khamar dan babi yang dimiliki kaum zimmi juga hatus dimusnahkan.

Pemusnahan terhadap harta benda yang dilakukan oleh seseorang semata-mata karena melaksanakan tugas (perintah dalam konteks ketaatan) seperti para pembantu hakim, tidak dibebani ganti rugi. Berbeda, misalnya perintah itu dalam konteks maksiat, maka ganti rugi menjadi suatu kewajiban.

Apabila sesuatu yang diperintah tergolong boleh dilakukan (ja'iz al-fi') serta dikerjakan atas dasar ketaatan terhadap perintah - ketaatan seorang pegawai terhadap atasan, misalnya — maka dalam hal ini perbuatan orang yang diperintah sama dengan perbuatan orang yang memberi perintah. Dengan demikian ganti rugi dibebankan kepada yang memberi perintah, dengan catatan jika perbuatan tersebut memang benar-benar mengharuskan ganti rugi.

b) Melakukan sesuatu yang merugikan orang lain dalam keadaan darurat. Misalnya melakukan perusakan terhadap harta benda orang lain, dalam keadaan terancam baik jiwa maupun hartanya oleh orang lain atau hewan, tidak dibebankan ganti rugi. Tentu saja terikat dengan syarat-syarat tertentu. Misalnya mencegah terjadinya suatu kerugian dengan melakukan sesuatu yang merugikan pihak lain harus bersifat tiba-tiba dan seketika. Tanpa direncanakan sebelumnya.

c) Keadaan darurat (balat al-darurab). Apabila seseorang dalam keadaan lapar atau haus yang dapat mengakibatkan kematiannya. Untuk mencegah kematian tersebut diperbolehkan makan atau minum milik orang lain, dengan syarat tidak melebihi kebutuhan. Dalam keadaan seperti ini kewajiban ganti rugi menjadi gugur, tetapi ia diwajibkan untuk membayar makanan dan minuman itu sebagai pengamalan dari kaidah:

الضرورات تييح المطورات ، الضرورة تقدر بقدرها ، الاضطرار لا يبطل حت الغير .

Pendapat tersebut disepakati oleh mazhab empat dan juga pendapat mazhab Zaidiyah.

d) Ada kerelaan dari pibak yang dirugikan. Jika seseorang memetintahkan orang lain untuk membuang bajunya ke laut, atau merusak rumahnya, ternyata perintah itu dilakukan, maka orang tersebut tidak dibebani ganti rugi. Sebab, perintah untuk melakukan hal tersebut, masih dalam batas wervenangnya. Lagipula, yang melakukan perintah tersebut tidak termasuk pelaku pelanggaran (muta'addi).

e) Apabila pembebanan ganti rugi itu tidak berguna ('adamu al-faidab fi al-tadbmin). Jika kaum muslim memusnahkan harta benda kaum pemberontak (al-bugat), atau 
sebaliknya al-bugat memusnahkan harta benda kaum muslim, masing-masing tidak dapat dibebani ganti rugi. Sebab, pembebanan ganti rugi kepada mereka tidak berguna. Umat Islam tidak boleh menanggung ganti rugi terhadap harta benda otang-orang bugat. Sebaliknya orang muslim pun tidak dapat memberlakukan ganti rugi terhadap kaum bugat mengingat tidak ada kewenangan pemerintah muslim terhadap mereka. ${ }^{25}$

\section{J. Perubahan Status Yadur Amanah ${ }^{27}$ Menjadi Yadu Dhamanah}

'Tidak terdapat perbedaan antara para fuqaha' bahwa yad al-wadi' (orang yang menerima titipan), al-mustajjir (penyewa), al-mudarib (pelaku usaha), al-syarik (mitra usaha), al-rasul (utusan), al-ajir al-khas, wakil sukarela, wali, wasi, al-multagith atau orang yang menemukan dan memungut barang yang bertujuan untuk memperkenalkan barang adalah yadu amanah. Mereka tidak dibebani ganti rugi jika terjadi kerusakan barang pada saat berada dalam penguasaan mereka, kecuali kalau melakukan pelanggaran dan kecerobohan ( $a^{\prime} a d d i$ dan tafrith). Karena tangan-tangan ini secara

${ }^{25}$ Ibn Abidin (1994), Raddu al-Mukbtar' ala al-Dumi al-Mukbtar, Beirut: Dat al-Kutub al-ilmiyah, Cet I, jilid. V, p. 140, lihat juga Muhammad Ibn Ahmad al-Dasuqi (1996), Hasyiyat 'ala alSyarb al-Kabir, Beirut Dar al-Kutub al-ilmiyah, Cet.I, Jilid. IV, p. 240.

${ }^{25}$ Al-yad menuru bahasa adalah salah satu anggota badan yang disebut tangan. Dalam pengertian majazi dapat bermakna nikmat, penguasaan terhadap sesuatu barang, kepemilikan atau juga dapat bermakna kekuatan. Menurut al-Zarkasyi, alyad ada dua macam, yakni yad bissiyah yaitu tangan dalam pengertian konkret dan yad ma'nawiyah yaitu tangan dalam pengertian abstrak. Yad hissiyah adalah mulai dari jari-jari sampai dengan siku. Adapun yad'ma'navijab maksudnya penguasaan tethadap suatu barang baik karena kepemilikan maupun karena lainnya, karena dengan al-yad atau penguasaan tethadap suatu barang dapat ditasarrufkan (ditukar, dijual dan lain-lain). Lihat Badruddin al-Zarkasyi $(1405 \mathrm{H}$ ), alMantsurfi al-Qava'id, Dat al-Kuwait, Cet. II, Jilid. III, p. 370. Para fuqaha' kemudian membagi al-yad alma'naniyah menjadi yad dhaman dan yad amanah. Yad dhaman adalah yad yang menguasai barang (al-haiz li als'ai) tanpa seizin pemiliknya. Penguasaan dengan cara merampas, mencuri atau dengan cara lain yang tergolong 'udwan. Atau menguasai barang dengan seizin perniliknya akan tetapi dengan maksud memilikinya seperi mengambil barang dengan menuntut agar pemilik menjual barang tersebut kepadanya, dan pemungut barang (al-multaqith) dengan niat untuk memiliki. Menurut mazhab Syafi'iyah dan Hanabilah, yad al-musta' ir (peminjam) adalah yad dhaman. Pendapat ini disepakati oleh mazhab Malikiyah pada jenis barangyang dapat disembunyikan seperti perhiasan dan pakaian. Mazhab Hanafiyah juga berpendapat :bahwa yad al-murtahin (penerima gadai) adalah yad dhaman. Demikian pula pendapat mazhab Maliki terutama pada barang-batang yang dapat disembunyikan. Lihat Ali Ibn Muhammad al-Mawardi (1994) al-Havi al-Kabir Syarh Mukhtasar al-Murani, Beitut: Dar al-Kutub al-ilmiyah, Cet. I, Jilid VIII, p. 191; jilid IX, p. 254 dan 255. Lihat juga Ahmad Ibn Idris al-Qurafi, al-Furuqfi Anvar al-Buriqfi Anvai al-Furuq, op. cit. Jilid II, p. 207; Badruddin Zarkasyi, Ibid. Jilid II, p. 323,332, 339; Abdurrahman Ibn Syihabuddin Ibn Rajab (1997), al-Qava'id al-Fiqhiyab, Kairo, p. 60; Muhammad Ibn Ahmad al-Syarbini (1994), Mugbni alMubtaj, Beirut: Dar Kutub al-ilmiyah, Cet. I, Jilid. II, p. 267; dan Ibn Rusyd al-Hafid (1997), Biddyat alMujtahid, Beirut: Dar al-Kutub al-ilmiyah, Cet. I, Jilid. II, p. 263.

${ }^{27}$ Amanah dalam istilah figh adalah kepercayaan yang diberikan kepada seseorang betkaitan dengan pemeliharaan harta benda betdasarkan suatu akad atau bukan akad, baik akad itu tergolong akad istibfar 
keseluruhan tergolong penolong (al-irfaq wa al-ma'unab). ${ }^{28} \mathrm{Jika}$ tangan-tangan mereka dibebani ganti rugi, maka kepentingan publik akan terabaikan.

Aakan tetapi fuqaha' berbeda pendapat pada sebagian al-yad yang lain seperti yad al-musta'ir (peminjam barang), yad al-murtabin (penerima gadai), yad al-wakil dengan upah, yad ajir al-musytarak, dan yad sunna' (pembuat barang pada akad istisna'). Sebagian fuqaha' berpendapat bahwa tangan-tangan mereka termasuk tangan amanah sehingga kalau terjadi kerusakan barang tidak dibebani ganti rugi. Sedangkan fuqaha' yang lain berpendapat bahwa tangan-tangan mereka adalah yadu dhaman, artinya jika terjadi kerusakan pada barang pada saat dalam mpenguasaan mereka dibebani ganti rugi. ${ }^{29}$

Perbedaan pendapat tersebut muncul karena beberapa sebab. Pertama: Sebagian al-aidi (jamak dari al-yad) tersebut dari satu sisi memiliki kemiripan secara dominan dengan al-aidi al-aminah, sedang di sisi lain kemiripannya juga dominan dengan alaidi al-daminab. Fuqaha yang mentarjih kemiripannya dengan al-aidi al-aminab menjadikannya bagian dari yad amanab sendiri, sebaliknya fuqaha' yang mentarjih kemiripannya dengan al-aidi al-daminab menjadikannya bagian dari al-yad al-daminab. ${ }^{30}$

Kedua sebagian fuqaha' melakukan istibsan untuk menetapkan ganti rugi terhadap al-aidi al-aminab untuk mengantisipasi kerugian akibat kerusakan barang karena suatu kecerobohan dan kelalaian mereka. Ketiga terdapat perbedaan pendapat tentang subut-nya sejumlah nas yang berkaitan dengan al-aidi. Misalnya hadis: 'ala al musta'ini ghaira al mugbilli dbamanun, ${ }^{31}$ dan 'ala al yadi ma akbadrat hatta tuaddibi ${ }^{32}$ dan wa la tabun man khanaka ${ }^{33}$ dan anna Rasulallabi ista'ara min Shafwana ibni Umawijyab

(akad pemeliharaan barang) seperti wadi'ah, maupun akad istijar (akad untuk penggunaan jasa barang) . seperti ijarah. Amanah yang tanpa menggunakan akad seperti lugatbob (barang pungutan) yang berda pada al-multagith selama dalam penyiarannya. Sedangkan di dalam Majallatu al-Abkan al-Adliyab menyebutkan bahwa amanah adalah sesuatu yang dipercayakan kepada seseorang berupa akad, seperti harta benda yang disewakan atau yang dipinjamkan, maupun harta yang berada di tangan otang lain tanpa melalui akad atau tanpa kesengajaan. Sedangkan al-amin adalah orang-orang yang sedang mengemban amanah. Lihat Muhammad Ruwas Qol'aji dan Hamid Sodiq Qunaibi (1988), Mu'jam Lugat al-Fuqaba' 'Arabi-Inklizi, Beirut: Dar'al-Nafa'is, Cet.II,

${ }^{28}$ Ali Ibn Muhammad Al-Mawardi, Ibid Jilid. VIII, p. 192, 394, IX, p. 104, X, p. 385.

${ }^{29}$ Lihat referensi sejumlah fiqh klasik dalam Nazih Hammad (2001), Qodoya Fighiyab Mu'asirabfi al-mal wa al-Igtisad, Damaskus: Dar al-Qalam, Cet. I, p. 370.

${ }^{30}$ Lihat al-Mrgaddimat al-mumabbiddt, hal. 2/246,368, Ali Ibn Muhammad Al-Mawardi, Ibid Jilid VII. p. 191, IX, p. 254, Ahmad Ibn Idris al-Qurafi, op. cit. Jilid. II. p. 207, Abdurrahman Ibn Syihabuddin Ibn Rajab.op. cit. p. 60, Kasyfu al-Qina', hal. 92, al-Zakhirah, hal. 8/112.

${ }^{31}$ Diriwayatkan oleh Daral-quthni dan al-Baihaqi dari hadis 'Amr ibn Syu'aib dari ayahnya dan kakeknya. Datal-quthni menda'ifkan hadis ini. Ibn Hajar berkata: dalam isnadnya ada dua orang yang da'if. Lihat Ibn Hajar al-Asqalani (1384), al-Talkbis al-Habir fi Takhrij Ahadis al-Rafi T al-Kabir, Mesir: Syarikat al-Thiba'ah al-Fanniyah, Jilid III, p. 97, dan Muhammad Ali al-Syaukani, op. cit, Jilid V, p. 296.

${ }^{32}$ Diriwayatkan oleh $A$ bu Daud, Tirmizi, Ibn majah dan lain-lain. Hadis ini juga da'if. Lihat Ibn Hajar al-Asqalani, ibid, Jilid. III. p. 353 dan Muhammad Ali al-Syaukani, op. cit, Jilid V, p. 298.

${ }^{33}$ Diriwayatkan oleh Abu Daud, Tirmizi, al-Daromi, dan lain-lain, kendati diakui sebagai hadis 
adra'an yauma Hunaini, faqala: aghasban ya Mubammad?, faqala: bal 'ariyatan madbmunatan ${ }^{34}$

Terlepas dari silang pendapat tersebut status yadu amanah dapat berubah menjadi yadu dhamanab karena antara lain pertimbagan 'urf atau tradisi kolektif yang berlaku di tengah masyarakat. Pendapat ini umum di kalangan fuqaha' Hanafiyah dan Malikiyah. Mereka kemudian mengemukakan kaidah fiqh yang betkaitan dengan al'urf yaitu:

اللعادة محكمة

$$
\text { العرف حجة يلزم العرل به ما لم يخالف نصا شرعيا }
$$

Contoh konkret mengenai masalah tersebut dapat ditemukan dalam fiqh mazhab Hanbali yang mengatakan bahwa para hurras (tukang jaga, satpam untuk masa sekarang) barang tidak dapat dibebankan ganti rugi. Sebab mereka tergolong yadu amanab. Namun demikian, seperti dikemukakan oleh penulis Kasyfu al-Qina,,35 para hurras tersebut sewaktu-waktu dapat dibebani ganti rugi berdasarkan pertimbangan al-urf: Beliau mengatakan:

$$
\text { والعرف الآن ضمان الحارسين ، لأغمم يستأجرون على ذلك }
$$

Makna yang sama juga dikemukakan oleh Ibn Nujaim, seorang faqih penganut mazhab Hanafi, ketika menjawab pertanyaan dan mengomentari kaidah: al ma'rufu ka al masyarut. Beliau mengatakan:

$$
\begin{aligned}
& \text { وقد جرى العرف في المطابخ بضمانا على المستأحر فأجبتث بأن المعروف كالمشروط ، فصار كأنه صرح } \\
& \text { بضماذا ـ والعارية إذا الشترط فيها الضمان على المستعير تصير مضمونة عندنا في رواية. }
\end{aligned}
$$

Jadi, menurut Ibn Nujaim, para pekerja dan peminjam barang dikenakan ganti rugi jika terjadi kerusakan akibat kecerobohan atau kelalaian.

Selain faktor 'urf, unsur ta'addi (perlakuan yang melampaui wewenang baik secara syara' maupun 'urf) juga dapat menyebabkan ganti rugi bagi yad amanah. Hal, ini menjadi kesepakatan para fuqaha' seperti ta'addi yang dilakukan oleh al-wadi' (yang diberi kepercayaan memegang titipan) terhadap al-wadi'ab (titipan) dengan merusak atau memanfaatkan tanpa seizin pemiliknya. Atau juga ta'addi yang dilakukan oleh mudharib (yang melakukan usaha dalam akad mudarabab) ketika mengerjakan sesuatu di luar kontrak dengan sabib al-mal (pemilik modal). Seperti juga al-ta'addi yang dilakukan oleh al-ajir (tenaga sewaan/orang upahan) dengan

hasan oleh Tirmizi, namun Syafi'i mengatakan bahwa hadis ini tidak tsabit.

${ }^{34}$ Diriwayatkan oleh Abu Daud, Tirmizi, Nasa'i, Ibn Majah dan lain-lain. Sebagian ulama mensahihkan hadis ini. Tetapi menurut Syaukani jalan hadis ini dianggap cacat oleh Ibn Hazm dan Ibn Qattan. Lihat Ibn Hajar al-Asqalani, ibid, Jilid. III. p.52.

${ }^{35}$ Al-Buhuti (1394H.), Kasy-syaf'al-qina', Makkah: Mathba'ah al-Hukumah, p. 69.

${ }^{36}$ Al-Qori (1401H.), Majallatu al-Abkam al-Adliyah 'ala Maqhabi Ahmad, Jedah: Tihamah, $1401 \mathrm{H}$. 
tidak mengindahkan perintah al-mustajjir (orang yang menyewa tenaga), atau juga tindakan wakil (wakil) yang melampaui wewenang yang didelegasikan oleh al-muwakkil (pihak yang diwakili). Mereka ini terkena kewajiban dhaman karena sebagai pelaku langsung (mubasyir) yang mengakibatkan kerusakan, atau penyebab rusaknya barang secara zalim dan adanya unsur permusuhan.

Jika terjadi perselisihan antara al-amin dengan sabib al-mal tentang prilaku ta'addi ini, maka penyelesaiannya diserahkan kepada ahli atau orang yang memiliki kompetensi untuk itu. Solusi seperti ini sesuai dengan petunjuk Majallatu al-Abkam al-Syar'iyab 'ala Mazhabi Abmad".

Al-tafrith menurut bahasa al-tagshir dan al-tadbyi' (kelalain, kealpaan, kesembronoan). Sedangkan al-Ifrath bermakna al-israf wa mujawazatu al-bad (melampaui batas, pemborosan). Menurut al-Jurjani ${ }^{37}$ al-ifrath digunakan pada kesewenangan yang betlebihan melampaui porsi yang normal (tajawazu al-bad min janib al-ziyadab wa al-kamal). Sedangkan al-tafrith digunakan pada sikap minimalis yang tidak proporsional (tajawazu al-had min jibat al-nuqshon wa al-taqshir).

Para fuqaha' sepakat bahwa yadu amanab dapat berubah status menjadi yadu dhamanab karena perilaku tafrith. Hal ini bisa terjadi pada mudharib, wadi', dan musta'jir. Standar tafrith yang mengharuskan dhaman itu ditakar dengan al-urf. Sedangkan tatawnu'ul amin bi iltizam ad-dhaman ba'da al-aqdi (kesanggupan dan kerelaan dari alamin secara suka rela untuk melakukan ganti rugi setelah akad), menurut mazhab Maliki termasuk dalam kategori tabarru'.

Selain itu, pertimbangan maslabab juga dapat memposisikan yadu amanab menjadi yadu dbamanah. Tentunya kemaslahatan pihak yang dikorbankan. Terakhir adalah altubmah. Maksudnya, terdapat dugaan kuat bahwa terjadi kebohongan dari al-amin yang menyatakan bahwa kerusakan barang bukan karena kelalaian atau kecerobohannya, melainkan faktor lain di luar kemampuannya. Klaim seperti ini sangat mungkin dilakukan oleh mereka yang berstatus yadu amanah yang tidak menyadari tanggung jawabnya. Atas dasar ini ganti rugi tetap diberlakukan kepada mereka.

Demikian pula yadu amanab berubah menjadi yadu dhamanab karena syaratsyarat yang ditetapkan secara sepihak (isytirath dhaman 'ala al-amin), namun mendapat persetujuan dari pihak yadu amanab baik itu mudbarib, musta'jir, wadi', wakil, syarik atau lainnya. Tetang masalah ini terdapat silang pendapat di antara para fuqaha'. Pendapat pertama, syatat yang ditetapkan tersebut adalah batal karena tidak sejalan dengan karakteristik akad yang berstatus amanah. Pendapat ini dikemukakan oleh fuqaha' Hanafiyah, Syafi'iyah, Malikiyah, dan fuqaha' Hanabilah dalam salah satu pendapat mereka yang populer. Pendapat tersebut juga dikemukakan oleh al-Sauri,

${ }^{37}$ Syarif al-Jurjani (1971), al-Ta'rifat, al-Dar al-Tunisiyah li al-Nasyr, p. 43. 
Auza'i, Ishaq, Nakha'i, dan Ibn al-Munzir. Atas dasar pendapat ini muncul kaidah fiqh dalam mazhab Hanafi yaitu; isthiratu ad dhiman 'ala al amini bathilun.

Pendapat kedua, menetapkan syarat karena faktor yang mengkhawatirkan pemilik modal misalnya, dapat dibenarkan dan dibetlakukan jika sesuatu yang dikhawatirkan itu dalam kenyataannya merusak barang sehingga mengakibatkan kerugian pada pemilik modal. Pendapat ini dikemukakan oleh Mutharrif dari mazhab Maliki.

Pendapat ketiga, syarat tersebut sahih dan mengikat. Pendapat ini dikemukakan oleh Qatadah, Usman al-Buttiy, Ubaidillah ibn Hasan al-Ánbari, Dawud al-Zahiri dan Ahmad dalam salah satu riwayatnya. Walaupun pendapat ini kurang populer di kalangan fuqaha' Malikiyah, dan pendapat yang tergolong lemah dalam mazhab Hanafi, namun pendapat ini mendapat dukungan dari Imam Syaukani, beliau mengatakan:

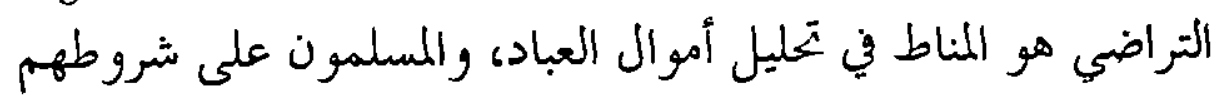

\section{Penutup}

Ide dhaman dalam hukum Islam bersamaan dengan datangnya sumber hukum Islam sendiri. Sejumlah ayat dan hadis secara eksplisit telah mengisyaratkan dhaman ini. Lalu kemudian dikembangkan oleh para fuqaha' dalam kontek perdata dan pidana. Dalam konteks perdata para fuqaha, khususnya al-Qurofi dan al-Tz Ibn Abdi Salam menggunakan istilah al-zawajir. Sedangkan dalam kontek pidana mereka menggunakan istilah al-zawajir. Adapun istilah al-masuliyah baru banyak ditemukan dalam fiqh-fiqh karya ahli hukum Islam modem.

Secara garis besar dhaman muncul karena darar badaniyah, darar maliyab dan darar sangat mungkin terjadi di luar fisik dan harta, seperti pencemaran nama baik. Tetapi terdapat darar yang kualifikasinya tidak mudah dinominalkan dengan ganti tugi dalam bentuk uang misalnya. Karena itu berapa jumlah ganti rugi yang harus dibayarkan selain yang tidak ditetapkan berdasarkan nas. Persoalan ini kembali kepada al-urf yang berlaku di masyarakat. Karena itu besarnya ganti rugi dapat ditetapkan berdasarkan kesepakatan para pihak. Jika cara ini sulit dilakukan maka besarnya ganti rugi ditetapkan berdasarkan ketetapan dari pembuat undang-undang. Namun demikian seorang hakim punya wewenang untuk menetapkan nominal ganti rugi asal sesuai dengan prinsip-prinsip penetapan ganti rugi dan tidak bertentangan dengan rasa keadilan. 


\section{DAFTAR PUSTAKA}

Ahmad Ibn Idris al-Qurafi (1998), al-Furuq fi Anwar al-Buruq fi Anvai al-Furuq, Mansyurat.

Muhammad Ali Baidhun (tt), Beirut: Dar al-Kutub al-jilmiyah.

Ahmad Ibn Muhammad al-Harnawy (1405 H/1985), Gamu Uyûni al-Basha'ir wa Syarab al-Asybâh wa al-Nâza'ir, Bairut: Dar al-Kutub al-'ilmiah.

al-Bagdadi (1388 H), Majma' al-Dhamanat, Mesir: al-Khairiyah.

Al-Buhuti (1394H.), Kasy-syaf'al-qina', Makkah: Mathba'ah al-Hukumah.

Al-Fatlawi, Shahib 'Ubaid, Dhaman al-zuyub watakballafa al-muwasafat fi Uqud alBai,' Amman: Maktabah Dar al-Saqofah li al-Nasyr wa al-tauzi.

Ali Ibn Muhammad al-Mawatdi (1994) al-Hawi al-Kabir Syarb Mukbtasar al-Muizani, Beirut: Dar al-Kutub al-ilmiyah.

al-Muassasah al-Jami'iyyah li al-Dirâsat wa al-Nasyr wa al-Tauzi.

Al-Qori (1401H.), Majallatu al-Abkam al-Adliyab 'ala Mazbabi Abmad, Jedah: Tihamah.

Al-Quran al-Karim

Al-Sarakhsi $(1324 \mathrm{H})$, al-Mabsut, Mesir: al-Sa'adah.

Atasi (135 H.), Syarab Majallatu al-Abkam al-Adliyah, dicetak di Hims Suriah.

Badruddin al-Zarkasyi (1405 H.), al-Mantsur fi al-Qawa'id, Dar al-Kuwait.

Ibn Abidin (1994), Raddu al-Mukbtar 'ala al-Durri al-Mukhtar, Beirut: Dar al-Kutub al-ilmiyah.

Ibn Hajar al-Asqalani (1384), al-Talkhis al-Habir fi Takbrij Abadis al-RafíT al-Kabir, Mesir: Syarikat al-Thiba'ah al-Fanniyah.

Ibn Rusyd al-Hafid (1997), Bidayat al-Mujtabid, Beirut: Dat al-Kutub al-ilmiyah. Ibn Syihabuddin Ibn Rajab (1997), al-Qawa'id al-Fiqbiyab, Kairo.

Ibrahim Fadil al-Dabbo (1997), Dhaman al-Manafi' Dirasab Muqaranah fi al-Figh alislami wa al-Qanun al-Madani, Amman, Beirut: Dar al-Bayariq, Dat 'Ammat. Jalaluddin Al-Suyuthi (1994), al-Asybab wa al-Naza'ir, Beirut: Muassasah al-Kutub al-Saqofiyah.

Majduddin al-Fairuzabadi (tt), al-Qamus al-Mubit, Kaito: Dar al-Hadis.

Muhammad Ahmad Siraj (tt), Dhaman al-'Udwan fi al-Fiqh al-Islami (Dirâsah . Fiqhiyah Muqâtanah bi ahkâm al-masuliyah al-Taqshiriyah fi al-qanun).

Muhammad Ali As-Syaukani (1380 H), Nail al-Authar Syarb Muntaqa al-Akbbar, Mesir: Mústafa al-Babi al-Halabi.

Muhammad Ibn Ahmad al-Dasuqi (1996), Hasyiyab 'ala al-Syarb al-Kabir, Beirut: Dat al-Kutub al-ilmiyah.

Muhatnmad Ibn Ahmad al-Syarbini (1994), Mugbni al-Mubtaj, Beirut: Dar Kutub alilmiyah. 
Muhammad Ruwas Qol'aji dan Hamid Sodiq Qunaibi (1988), Mu'jam Lugat al-Fuqaba' "Arabi-Inklizi, Beirut: Dar'al-Nafa'is.

Mustofa Ahmad al-Zarqa' (tt), al-Madkhal al-Fiqhi al-Am (al-Figh al-Islami fi Saubibi al-jadid), Beirut: Dar al-Fikt.

Nazih Hammad (2001), Qodoya Fiqhiyah Mu'asirah fi al-mal wa al-Iqtisad, Damaskus: Dar al-Qalam.

Syarif al-Jurjani (1971), al-Ta'rifat, al-Dar al-Tunisiyah li al-Nasyr.

Usman Ibn Ali al-Zaila'i (1990), Tabyin al-bagoiq Syarb Kañu al-Dagaiq, Kairo: Dar al-Kitab al-Islami.

Wahbah al-Zuhaily (1995), al-Mas'uliyab 'an Filli al-Gair, Damaskus: Dar al-Muktabi. 